\title{
Pengembangan dan Pemanfaatan Tema Pembelajaran Dalam Penggubahan dan Penciptaan Lagu Anak Usia Dini
}

\author{
Itot Bian Raharjo', Warih Handayaningrum², Autar Abdillah ${ }^{3}$ \\ ${ }^{1}$ Universitas Nusantara PGRI Kediri, Indonesia \\ ${ }^{2,3}$ Pascasarjana Pendidikan Seni Budaya, Universitas Negeri Surabaya, Surabaya, Indonesia \\ Email: itotbian@unpkediri.ac.id,warihhandayaningrum@unesa.ac.id, autar.unesa@gmail.com
}

\begin{abstract}
Learning in early childhood education cannot be separated from musical activities. In practice, musical activities can be carried out to develop 5 aspects of early childhood development, including aspects of cognitive development, religious and moral values, language, physical motoric, and social emotional. This study uses a qualitative descriptive approach with the research subjects being IGTKI and IGRA teachers in Kediri Regency who are taking PG-PAUD lectures at Nusantara University PGRI Kediri with a study period in semester V with a total of 20 respondents. It can be identified that they have various musical abilities, namely solfegio skills, the ability to play melodic instruments, and can't play music. Data obtained through interviews, documentation, and observation. Data analysis using interactive analysis. It can be concluded that composing song lyrics can increase creativity and creating new songs is an alternative choice in increasing the vocabulary of early childhood songs.
\end{abstract}

Keywords: learning themes, composing, creating, early childhood

\begin{abstract}
Abstrak: Pembelajaran di Pendidikan anak usia dini tidak lepas dari aktivitas bermusik. Dalam pelaksanaan, aktivitas bermusik dapat dilaksanakan untuk mengembangkan 5 aspek perkembangan anak usia dini, antara lain aspek perkembangan kognitif, nilai agama dan moral, bahasa, fisik motorik, dan sosial emosional. Penelitian ini menggunakan pendekatan deskriptif kualitatif dengan subjek penelitian adalah guru IGTKI dan IGRA Kabupaten Kediri yang menempuh perkuliahan PG-PAUD di Universitas Nusantara PGRI Kediri dengan masa studi di semester $\mathrm{V}$ dengan jumlah sebanyak 20 responden. Dapat diidentifikasi bahwa kemampuan musikal yang dimiliki beragam, yaitu kemampuan solfegio, kemampuan memainkan alat musik melodis, tidak bisa musik. Data diperoleh melalui wawancara, dokumentasi, dan observasi. Analisis data menggunakan analisis interactive. Dapat disimpulkan bahwa penggubahan lirik lagu dapat meningkatkan kreativitas dan mencipta lagu baru adalah alternatif pilihan dalam menambah perbendaharaan lagu anak usia dini.
\end{abstract}

Kata Kunci: tema pembelajaran, menggubah, mencipta, anak usia dini

\section{Article info:}

Received: 19 April 2021

Reviewed: 20 April 2021

Accepted: 30 Juni 2021

\section{PENDAHULUAN}

Pendidikan mempunyai peranan yang sangat penting bagi bangsa, generasi penerus bangsa mewarisi budaya melalui Pendidikan berupa kognitif, afektif, dan psikomotorik. Pendidikan penting untuk anak karena melalui Pendidikan maka anak akan mendapat bermacammacam ilmu pengetahuan dan wawasan agar menunjang 5 aspek perkembangan tersebut. Untuk itu, sangatlah tepat jika Pendidikan diawali dari masa usia dini (Undang-Undang Republik Indonesia, 2003).

Peranan utama dalam mencapai tujuan Pendidikan Nasional diawali dari Pendidikan prasekolah yaitu Pendidikan Anak Usia Dini. Dalam peningkatan 5 aspek perkembangan yang sesuai dengan (Peraturan Pemerintah Republik Indonesia, 2021) tentang standar Pendidikan, guru PAUD sangat berperan penting dalam memberikan kemampuan/ aspek perkembangan 
dasar dalam mengembangkan kognisi, psikomotoris, dan afeksi yang nantinya sangat dibutuhkan dalam berinteraksi dengan lingkungan sosial, serta jenjang perkembangan selanjutnya yaitu Pendidikan dasar, Pendidikan menengah, dan Pendidikan tinggi.

Pembelajaran merupakan aktivitas yang sangat kompleks. Pada hakikatnya pembelajaran tidak sekedar guru menyampaikan pesan pada materi yang disampaikan, namun juga aktivitas profesional yang menuntut guru agar menggunakan kemampuan dasar dalam mengjar secara terpadu dengan terciptanya situasi atau kondisi belajar yang efisien (Mashudi, 2013). Dalam aktivitas belajar, guru harus dapat mendesain strategi belajar sehingga anak dapat tertarik atau termotivasi. Dapat dikatakan pembelajaran tersebut berkualitas jika adanya motivasi, adanya target belajar yang terukur, adanya desain pembelajaran yang baik, dan lain sebagainya.

Masa prasekolah adalah periodisasi yang berarti dalam meningkatkan perkembangan bahasa anak. Kemampuan yang diharapkan adalah memahami/ mengerti semua arti tentang apa yang disampaikan/diucapkan oleh orang lain. Anak usia dini mulai mengerti dan menyadari bahwa kemampuan berbahasa anak merupakan media audiotorial yang penting dalam komunikasi dan bersosial. Sheppard (2007) mengemukakan bahwa musik bisa membantu pembentukan fungsi otak, pertumbuhan otak, sistem koordinasi fisik dan mental, meningkatnya daya ingatan, perkembangan kemampuan bahasa, peningkatan kemampuan matematis, kreativitas personal, pengembangan keterampilan sosial, dan Kesehatan. Dengan fokus perkembangan melalui pembentukan afeksi (perilaku), maka dipersiapkannya anak usia dini dengan pemahaman sikap dan perilaku yang didasarkan pada aspek perkembangan nilai agama dan moral serta aspek perkembangan sosial dan emosional; sedangkan pengembangan dasar berupa semua aktivitas yang diarahkan kepada pencapaian kemampuan cipta, daya fikir, keterampilan, kemampuan fisikal jasmani, dan bahasa yang disesuaikan dengan tahap tumbuh kembang anak.

Untuk memudahkan guru PAUD dalam pelaksanaan berbagai program aktivitas belajar, telah ditetapkan tema pembelajaran yang menjadi acuan dalam mengembangkan tingkat pencapaian belajar anak. Menurut Negara (2019), musik berperan sebagai fasilitator dalam pengembangan kognisi anak, kepekaan irama anak menjadi terlatih, motorik anak menjadi terlatih, membantu penguasaan bahasa, dan dapat menjadikan sarana dalam berkomunikasi yang baik.

Masa pra sekolah dapat diidentifikasi dengan adanya periode puncak emosi yang dapat dilihat dengan terlihatnya perilaku takut, perasaan yang berlebih, emosi tanpa penyebab yang terlihat meledak-ledak. Menurut Arostiyani (2013), bahwa lagu anak dapat digunakan sebagai media dalam menanamkan Pendidikan karakter. Proses Pendidikan karakter terlihat ketika guru mengajak anak untuk bernyanyi bersama, lalu menyampaikan arti/makna/isi yang terkandung pada lirik lagu. Makna tersebut antara lain: kejujuran, kedisiplinan, religious, kerja keras, kemandirian, demokratis, rasa keingintahuan, semangat dan jiwa kebangsaan, cinta tanah air, komunikatif, cinta perdamaian, perduli terhadap lingkungan, peduli terhadap sesama, dan bertanggungjawab. Terdapat beberapa kegiatan bermusik yang antara lainnya adalah mendengarkan musik, bernyanyi, memainkan alat musik ritmis dari daur ulang barang bekas, memainkan alat musik rebana, memainkan alat musik marching band, dan lainnya. Permainan musik ini berbentuk ritmis, melodis, dan harmonis sederhana (Suwono, 2011). Proses beraktivitas musik tersebut membuat anak lebih berarti, hal tersebut dikarenakan selain belajar merekapun juga bermain. Terkadang dibutuhkan kemampuan guru dalam berkreativitas berinovasi dengan mengembangkan perencanaan maupun proses pelaksanaan kegiatan. Menurut Jhon W. Haefele dalam Munfarijah (2015), kreativitas adalah kemampuan seseorang untuk menjadikan segala sesuatu menjadi baru dan memiliki nilai social; sedangkan menurut Debeturu dan Wijayaningsih (2019), kreativitas adalah kemampuan yang dipunyai seseorang dalam mencipta sebuah karya yang diperoleh dari beberapa ide, gagasan, dan imajinasi. Bermacam-macam media bisa digunakan sebagai perkusi yang sederhana, sehingga dengan sentuhan kreativitas dan inovasi guru, maka aktivitas ini dapat meningkatkan tumbuh kembang pada kecerdasan musikal anak (Cutietta, 2013). 
Agar proses peningkatan keterampilan tersebut dapat terlaksana secara efektif, maka disetiap tahapan berlatih harus didesain secara beruntut dan berkesinambungan, sehingga tingkat pencapaian atau optimalisasi dalam praktik (ketepatan dan kecepatan) melakukan aktivitas musik tersebut dapat dicapai oleh anak.

Sebuah lagu berdasarkan aspek perkembangan Bahasa, anak usia dini dapat memperoleh pengalaman berupa bertambahnya perbendaharaan kosa kata tentang: (1) Makna menghormati kedua orang tua; (2) Menyayangi sesame; (3) Mengagungi Tuhan dan mengagumi penciptaan-Nya; (4) Cinta akan tanah air, dan (5) Nilai-nilai budaya.

Selain itu, menyanyi membantu anak menuju kedewasaan dan tumbuh kembang aspek fisik, intelegensia, emosional dan jiwa sosial anak (Mahmud \& Fat, 1994); sedangkan unsur seni musik bila dikaitkan dengan kompetensi Bahasa maka dapat digunakan sebagai media dalam mengembangkan kemampuan baca dan sastra (intonasi, artikulasi, ekspresi, pemahaman kalimat). Musik merupakan salah satu kegiatan yang berarti dan bermakna dalam praktik pembelajaran di PAUD. Musik dirasa dapat mempengaruhi dan meningkatkan perkembangan kepribadian anak melalui 5 aspek perkembangan. Selain itu, musik tidak lepas dari aktivitas kita. Musik merupakan bagian dari dunia kita, ditunjukkan melalui perkembangan musik berdasarkan jamannya (abad pertengahan, renaissance, barok, klasik, romantik, modern). Sejarah musik juga menunjukkan sejarah manusia pada proses seni lainnya. Ekspresi musikal yang diketahui hingga saat ini adalah perwujudan dari pengalaman hidup pencipta maupun orang lain, dan merupakan ekspresi diri dan keberadaan manusia itu sendiri. Senada dengan itu, Aristoteles (dalam Rachmawati, 2005), mengatakan bahwa musik merupakan imitasi (tiruan) seluk beluk hati dengan melalui melodi dan irama.

Untuk meningkatkan kompetensi guru dalam mengajar, dibutuhkan keterampilan dalam menggubah dan mencipta lagu. Kemampuan tersebut tidak lepas dari kemampuan menyusun melodi lagu yang sederhana sesuai dengan karakteristik anak usia dini, yaitu melodi yang tidak terlalu melompat-lompat, range tidak lebih dari 1,5 oktaf, birama lagu yang memudahkan gerakan seperti 2/4 dan 4/4. Menggubah dapat diartikan sebagai mengaransemen, yang artinya menyadur sebuah komposisi yang berbeda dari komposisi sebelumnya dengan tujuan mempertahankan unsur sensi musikalnya, dan dengan proses adaptasi yang tidak jauh berbeda dari aslinya (Randel, 1986). Aransemen merupakan penulisan ulang sebuah komposisi dengan penggunaan instrument yang tidak sama dari karya sebelumnya (Ammer, 1979). Jika guru memiliki kemampuan tersebut maka dapat dikatakan bahwa ia merupakan seorang arranger. Dalam kajian ini adalah menggubah lirik lagu.

Mencipta lagu tidak lepas dari kemampuan musikal yang tinggi karena harus memiliki kemampuan ilmu harmoni dan ilmu bentuk musik. Ilmu harmoni untuk mencipta lagu anak usia dini (sederhana) antara lain trinada, kadens, dan nada tambahan. Sedangkan ilmu bentuk musik dalam cipta lagu anak (sederhana) meliputi struktur melodi, bentuk musik, musik polifoni, dan bentuk lagu.

Pembelajaran berbasis tema mengutamakan kepada penerapan konsep pembelajaran dengan melakukan suatu kegiatan (learning by doing). Untuk itu, guru perlu mendesain pengalaman belajar anak yang kenunjukkan keterkaitan unsur pendidikan berbasis konseptual sehingga prosses kegiatan pembelajaran menjadi lebih efektif. Sebagai sebuah model/ metode pembelajaran pada PAUD, pembelajaran berbasis tema mempunyai karakteristik yaitu: (1) Student centered; (2) Mendapat pengalaman secara langsung; (3) Pembelajaran berjalan terpadu; (4) Menyajikan dengan memberikan konsep dari sekian banyak pengetahuan; (5) Fleksibel; serta (6) Hasil dari proses belajar disesuaikan dengan minat dan kebutuhan anak (Yustisia, 2007).

Untuk lebih lanjutnya, tema yang dikembangkan dalam pendidikan anak usia dini meliputi: diri sendiri, kebutuhan, lingkungan, tanaman, binatang, transportasi, komunikasi, rekreasi, pekerjaan/ profesi, air udara dan api, dan negaraku. Pada pelaksanaannya, semua tema di atas disampaikan ke anak melalui aktivitas terpadu dengan memasukkan/ distimulus melalui aktivitas bermusik. Sebagai sebuah proses yang terintegrasi, kegiatan bermusik seperti mendengar/ menyimak musik, merespon bunyi musik dengan gerak berirama, menyanyikan lagu bersama, membaca makna simbol musik, dan memainkan alat musik sederhana, yang mana kegiatan tersebut memiliki 
fokus tujuan yaitu peningkatan aspek perkembangan anak usia dini.

Terkait dengan pembelajaran berbasis tema di atas maka penelitian tentang pengembangan dan pemanfaatan tema pembelajaran dalam mencipta lagu anak usia dini ini difokuskan yaitu:

1. Struktur lagu dan implementasi pada aspek perkembangan anak

2. Optimalisasi guru PAUD dalam menambah perbendaharaan lagu anak usia dini yang sesuai dengan tema pembelajaran melalui proses penggubahan dan penciptaan.

3. Kendala dalam Mengembangkan Lagu Anak Usia Dini

Beberapa hal yang perlu untuk diperhatikan adalah pembelajaran yang berbasis tema dimaksudkan supaya pelaksanaan dalam kegiatan pembelajaran lebih bermakna dan menyeluruh. Pertimbangan lainnya adalah alokasi waktu yang diperlukan untuk setiap tema, merperhitungkan ketersediaan bahan yang ada di sekitar lingkungan belajar (Semiawan, 2002). Tema pembelajaran merupakan wahana yang berisi bahan yang diperlukan pada perkembangan lanjutan dari guru dalam mengembangkan kegiatan pembelajaran. Berdasarkan tujuan pembelajaran yang berbasis tema, maka musik anak usia dini dapat dikembangkan melalui 11 tema yang ada.

\section{METODE}

Penelitian yang dilakukan ini menggunakan pendekatan deskriptif kualitatif dengan subjek penelitian adalah guru IGTKI dan guru IGRA yang berasal dari lingkup Eks. Karasidenan Kediri yang sedang menempuh Pendidikan Guru - Pendidikan Anak Usia Dini FKIP Universitas Nusantara PGRI Kediri. Pelaksanaan dilakukan di semester V tahun akademik 2019-2020 pada mata kuliah Keterampilan Seni Musik AUD. Jumlah keseluruhan sebanyak 20 responden dengan kemampuan musikal yang beragam, yaitu kemampuan solfegio, kemampuan memainkan alat musik (piano/ keyboard dan /atau gitar), dan juga ada yang tidak bisa musik sama sekali. Metode pengumpulan data melalui metode wawancara, dokumentasi, dan observasi. Analisis data menggunakan analisis interactive dari Miles dan Hubermann (Miles et al., 2014).

\section{HASIL DAN PEMBAHASAN Hasil}

Dalam pelaksanaan pembelajaran berbasis tema, terdapat langkah-langkah pembelajaran yaitu pemberian motivasi, prosedur pelaksanaan pembelajaran (kegiatan awal, inti, dan penutup), dan evaluasi pembelajaran. Pada tahapan awal pembelajaran, guru melaksanakan kegiatan dengan mebacakan teks atau lirik lagu lalu anak menirukan/menyebutkan kembali lirik tersebut, kemudian dilanjutkan dengan gerakan bertepuk tangan sebagai pengaplikasian tempo atau ketukan lagu atau ketukan birama lagu yang sesuai dengan tema pembelajaran. Aktivitas tersebut dilakukan dengan berulang-ulang. Meskipun rutinitas pada setiap harinya, sebelum memulai kegiatan pembelajaran pada pukul 07.30 selalu menyanyikan lagu seperti Indonesia Raya, kemudian lagu tema agar anak dapat terstimulus menuju tema pembelajaran. Rutinitas tersebut dilakukan untuk membangkitkan semangat pada masing-masing anak yang selanjutnya dapat menstimulus materi pembelajaran sesuai dengan tema yang sudah ditentukan.

Memanfaatkan tema lagu secara umum didapat melalui tatap muka yang dibangun atau dirancang dalam satu kali dalam satu minggu. Biasanya materi yang diberikan masih dalam satu rangkaian pembelajaran yang telah terprogram berdasarkan tema yang dikembangkan lagi melalui aktivitas bercerita (story telling) dan kegiatan lainnya yang dapat meningkatkan aspek perkembangan.

Dalam pelaksanaan pembelajaran di PAUD, guru dituntut untuk kreatif dalam menginovasikan sebuah aktivitas pembelajaran dengan memanfaatkan semuanya yang ada di sekitar. Beberapa yang bisa dilakukan guru PAUD dalam mengembangkan model pelaksanaan pembelajaran supaya menimbulkan kesan kebermaknaan yaitu mengetahui/ mengidentifikasi serta pengimplementasian lagu pada aktivitas peningkatan aspek perkembangan anak, penggubahan lirik lagu yang disesuaikan dengan tema, dan menciptakan lagu sesuai tema

\section{Struktur Lagu dan Implementasi pada Aspek perkembangan Anak}

Tema Binatang (Cicak-cicak di Dinding) Lirik:

Cicak-cicak di dinding 
Diam-diam merayap

Datang seekor nyamuk

Hap.... lalu ditangkap

1. Struktur lagu

a. Menggunakan birama 2/4

b. Memiliki alur melodi dengan lompatan nada sederhana

c. Lirik yang sesuai dengan pengalaman imajinatif anak saat menjumpai seekor cicak, sehingga mudah dihafalkan

d. Lagu ini memiliki jangkauan nada 1 oktaf

e. Lagu ini memiliki harga/ nilai notasi $1 / 2$ an dan $1 / 4$ an (1 ketuk dan maksimal $1 / 2$ ketukan)

f. Sajak AB (tanya - jawab)

2. Implementasi pada aspek perkembangan anak

a. Penggunaan birama $2 / 4$, mudah untuk dilakukan gerak dan lagu. Aktivitasnya adalah berkelompok lebih dari 3 anak berbaris ke belakang dengan baris kedua hingga berikutnya memegang pundak dari anak di depannya kemudian berjalan mengelilingi area belajar (aspek perkembangan motorik kasar dan sosial emosional)

b. Sesuai dengan imajinasi pada aktivitas yang dialami anak sehari-hari ketika malam hari menjumpai adanya cicak di dinding dan nyamuk yang terbang berkeliaran (aspek perkembangan kognitif)

Tema Alat Transportasi (Naik Kereta Api)

Lirik:

Naik kereta api....Jus...jus... jus...

Siapa hendak turun

Ke Bandung - Surabaya

Bolehkah naik dengan percuma

Ayo kawanku lekas naik

Keretaku 'tak berhenti lama

1. Struktur lagu

a. Menggunakan birama 2/4

b. Memiliki alur melodi dengan lompatan nada sederhana

c. Lirik lagu ini mengimajinasikan saat akan berangkat naik kereta, sehingga lirik lagu ini mudah untuk dihafalkan. Namun ada beberapa kata yang sedikit membingungkan anak yaitu "naik dengan percuma", mungkin orang dewasa bisa memahami bahwa maksud tersebut adalah anak kecil di bawah usia tertentu digratiskan/ tidak dikenakan biaya.

d. Lagu ini memiliki jangkauan nada 1 oktaf

e. Lagu ini memiliki harga/ nilai notasi $1 / 2$ an dan $1 / 4$ an (1 ketuk dan maksimal $1 / 2$ ketukan)

f. Bersajak AB (tanya - jawab)

2. Implementasi pada aspek perkembangan anak

a. Penggunaan birama $2 / 4$, mudah untuk dilakukan gerak dan lagu (aspek perkembangan motorik kasar dan sosial emosional)

b. Sesuai dengan imajinasi pada aktivitas yang dialami anak sehari-hari ketika bepergian menggunakan alat transportasi kereta api (aspek perkembangan kognitif)

Tema Kebutuhan (Bangun Tidur)

Lirik:

Bangun tidur ku terus mandi

Tidak lupa menggosok gigi

Habis mandi ku tolong ibu

Membersihkan tempat tidurku

1. Struktur lagu

a. Menggunakan birama 2/4

b. Memiliki alur melodi dengan lompatan nada sederhana

c. Lirik lagu ini memiliki pesan moral yang mendasar pada anak, terlihat dari runtutan lirik 1 hingga ke 4.

1) Lirik 1, pesan moral untuk tidak bermalasan yaitu setelah bangun tidur yang harus dilakukan yaitu mandi.

2) Lirik 2 , sebisanya ada pembiasaan saat mandi diikuti dengan aktivitas gosok gigi.

3) Lirik 3-4, pesan moral untuk membantu ibu dalam merapikan tempat tidur. 
d. Lagu ini memiliki jangkauan nada 1 oktaf

e. Lagu ini memiliki harga/ nilai notasi $1 / 2$ an dan $1 / 4$ an (1 ketuk dan maksimal $1 / 2$ ketukan)

f. Bersajak AA

2. Implementasi pada aspek perkembangan anak

a. Penggunaan birama 2/4, mudah untuk dilakukan gerak dan lagu. Aktivitasnya dilakukan secara individu dengan memperagakan gerakan cara bangun tidur, cara menggosok gigi, cara mandi, dan cara merapikan tempat tidur. Kegiatan tersebut termasuk dalam aktivitas bermain peran (aspek perkembangan kognitif)

b. Sesuai dengan imajinasi pada aktivitas yang dialami anak sehari-hari dengan menanamkan kedisiplinan ketika bangun tidur di pagi hari (aspek perkembangan sosial emosional)

Tema Rekreasi (Naik-Naik Ke Puncak Gunung)

Lirik:

Naik-naik ke puncak gunung

Tinggi-tinggi sekali $2 x$

Kiri kanan ku lihat saja

Banyak pohon cemara $2 x$

1. Struktur lagu

a. Birama yang digunakan adalah $3 / 4$

b. Lagu ini merupakan wujud pengalaman hidup ketika bertamasya

c. Memiliki alur melodi dengan lompatan nada sederhana

d. Lagu ini memiliki jangkauan nada 1 oktaf

e. Lagu ini memiliki harga/ nilai notasi $1 / 2$ an dan $1 / 4$ an (1 ketuk dan maksimal $1 / 2$ ketukan)

f. Bersajak AABB

2. Implementasi pada aspek perkembangan anak

a. Penggunaan birama 3/4, mudah untuk dilakukan gerak dan lagu. Dengan melakukan gerakan kiri 3 langkah dan kanan 3 langkah (aspek perkembangan motorik kasar dan sosial emosional)

b. Sesuai dengan imajinasi pada aktivitas yang dialami anak ketika diajak bertamasya ke daerah pegunungan (aspek perkembangan kognitif)

Banyak juga contoh lagu tematik lainnya yang sering digunakan guru PAUD dalam kegiatan pembelajaran, tanpa disadari bahwa lagu tersebut sering dibawakan dan bahkan bisa jadi lagu tersebut dibawakan turun temurun sejak kakek/ nenek kita, kedua orang tua kita, kita sebagai pengajar, dan anak didik kita. Dalam pelaksanaannya, aktivitas belajar bertujuan untuk mencapai tujuan belajar sesuai dengan perencanaan pembelajaran berbasis tema. Salah satunya adalah metode pelaksanaan berupa demonstrasi, tanya jawab, dan pemberian tugas. Yang mana ketiganya dijadikan pedoman untuk menilai aspek perkembangan anak.

Kelebihan jika anak mendemonstrasikan adalah setiap anak dapat mengenal atau mengetahui secara langsung tema atau lagu yang hendak dinyanyikan dan dipraktikan. Dan kelemahan dari demonstrasi jika guru kurang dapat mengkondisikan atau sulit mengatur kelas yang dikarenakan tugas yang diberikan guru kurang dimengerti oleh anak dan juga jika media yang digunakan kurang mendukung. Aktivitas yang dilakukan oleh guru saat penyampaian melalui metode praktik langsung atau interaktif atau keterampilan proses, dapat diketahui bahwa upaya guru menstimulus anak dalam melakukan gerak kepala, tangan, dan kaki dengan tujuan untuk menyampaikan pesan kepada anak yang terkait dengan tema yang diberikan. Sedangkan keikutsertaan melalui pemberian tugas dan tanya jawab, guru memberikan beberapa pertanyaan yang menstimulus anak untuk berfikir aktif. Selain itu, guru memerintahkan anak untuk maju ke depan dengan menyanyikan lagu di hadapan teman-temannya.

Hasil dari pembelajaran berbasis tema melalui lagu (media), mayoritas mengalami peningkatan aspek perkembangannya dengan ditunjukkannya tingkat pemahaman materi yang dipelajari menjadi meningkat. Contohnya ketika tema binatang diberikan ke anak, guru meminta 
anak untuk menunjukkan nama binatang yang sesuai dengan pertanyaan yang diajukan oleh guru dan jika hasil jawaban tersebut tepat serta anak berani untuk bertanya kepada guru tentang beberapa hal yang belum dimengerti terkait tema pembelajaran.

Optimalisasi guru PAUD dalam menambah perbendaharaan lagu anak usia dini yang sesuai dengan tema pembelajaran melalui proses penggubahan dan penciptaan

\section{Penggubahan Lirik Lagu}

Penggubahan lagu merupakan kemampuan dalam mengolah lirik lagu dari lirik asli menjadi lirik ubahan. Biasanya melodi lagu yang digunakan cenderung sama, hanya saja kadang dijumpai beberapa notasi mengalami perubahan harga notasi. Misalnya dari harga $1 / 4$ ketuk menjadi 1/8 ketuk, dari 1/8 ketuk menjadi 1/16 ketukan, dan seterusnya. Dalam Pusat Bahasa, Depdiknas (2008), Aransemen dapat disebut juga penggubahan lagu sesuai dengan komposisi yang diinginkan. Penggubahan musik merupakan sebuah karya seseorang yang bersumber dari ide atau karya musik yang sebelumnya telah ada dengan substansi dan esensi musik yang tetap dari sebelumnya.

Untuk mengetahui tingkat ketercapaian aspek perkembangan maka guru PAUD selalu mendapat informasi tersebut dari aktivitas demonstasi, tanya jawab, dan penugasan. Evaluasi yang diaplikasikan didapat dari penilaian secara individu dan kelompok, dari situlah dapat diketahui siapa saja yang dapat menyerap materi yang diberikan. Meskipun pada kenyataannya masih terdapatnya anak yang belum mampu menerima materi sesuai dengan harapan. Untuk mengatasi permasalahan tersebut, sebisanya guru memberikan perhatian khusus pada anak yang belum mampu menerima materi dengan memberikan materi lagu yang relative lebih mudah. Di dalam aktivitas belajar materi musik, anak belum dapat diberikan pemahaman simbol notasi musik seperti not balok maupun not angka. Sebisanya guru mengajarkan anak dengan memanipulasi simbol notasi dalam bentuk benda sesuai dengan tema lagu. Not angka dan not balok belum boleh diberikan ke anak didik karena kondisi anak pun dirasa sangat belia dan daya tangkap (realistis) masih terbatas, bahkan secara kondisi sosial maupun lingkungan kurang mendukung.
Pengembangan lagu anak usia dini yang dilakukan oleh guru dapat diketahui melalui aktivitas penggubahan lagu dengan melakukan improvisasi perubahan syair lagu dalam suatu kegiatan pembelajaran sesuai dengan tema pembelajaran. Kadang juga, guru mencari referensi instrumental lagu anak berbahasa Inggris (folklore) melalui internet. Aktivitas ini juga dapat membantu menambah perbendaharaan lagu anak dalam pelaksanaan kegiatan pembelajaran. Selain itu, guru sebisanya memanfaatkan perlengkapan elektronik seperti sound system yang dimiliki seperti speaker aktif, backsound, amplifier, speaker Bluetooth selama pelaksanaan pembelajaran (apersepsi, prosedur maupun evaluasi). Penggunaan alat pendukung tersebut sangat membantu dan memudahkan anak dalam menirukan apa yang dia dengar. Yang dibutuhkan dalam aktivitas musik tersebut memudahkan dalam penyesuaian dengan nada, irama, dan artikulasi dalam melafalkan lirik lagu yang dinyanyikan oleh anak.

Berikut ini adalah judul lagu berbahasa Inggris (folklore) yang digunakan dalam pembelajaran tema-tema di PAUD, lagu tersebut antara lain: twinkle twinkle little star, lightly row, song of the wind, o come little children, long long ago, dll. Dari melodi lagu yang dipilih tersebut kemudian diganti liriknya dengan lirik lagu sesuai dengan tema pembelajaran. Sekilas pasti akan diketahui lagu tersebut bagi pendengar, seperti wali murid, guru lain, dan lainnya. Namun aktivitas tersebut sangat wajar dilakukan oleh guru PAUD dalam mengembangkan pembelajaran serta dapat menambah perbendaharaan lagu anak usia dini. Sekilas memang jika dinyanyikan akan serasa mirip namun terdapat perbedaan yang tidak terlalu jauh atau signifikan pada notasinya. Hal tersebut dioptimalkan supaya dapat menyesuaikan notasi dengan syair dari lagu berbahasa Inggris (asli) dengan lagu gubahan berbahasa Indonesia walaupun syairnya berbeda karena penyesuaian tema, maupun memiliki syair yang sama (terjemahan lirik aslinya).

Contoh pada tema anggota tubuh, guru memilih lagu berbahasa Inggris dengan judul "Head Shoulders Knees and Toes" (my body) lalu diganti liriknya dengan lirik berbahasa Indonesia namun memiliki arti (translate) yang sama. Berikut ini cara penggubahannya: 
Itot Bian Raharjo ${ }^{1}$, Warih Handayaningrum ${ }^{2}$, Autar Abdillah ${ }^{3}$

Pengembangan dan Pemanfataan Tema Pembelajaran Dalam Penggubahan dan Penciptaan

Lagu Anak Usia Dini

Bahasa Inggris

Lyric:

Head Shoulders Knees and Toas

Head Shoulders Knees and Toas

And Eyes and Ears and Mouth and Nose

Head Shoulders Knees and Toas

Bahasa Indonesia

Lirik :

Kepala pundak lutut kaki (lutut kaki)

Kepala pundak lulut kaki (lutut kaki)

Mata telinga mulut hidung (dan pipi)

Kepala pundak lutut kaki (lutut kaki)

Dari lirik berbahasa Inggris, kemudian dirubah dalam bahasa Indonesia, maka dapat dilihat bahwa lagu dengan berbahasa Indonesia memiliki perubahan dengan menambahkan kata sahut menyahut pada kata "lutut kaki" dan "dan pipi". Tujuan dari penambahan lirik tersebut adalah untuk mengaktifkan respon anak dalam serangkaian kegiatan bernyanyi Bersama. Penambahan lirik ditujukan untuk menyesuaikan notasi dan syair dari asli (Inggris) menjadi bertambah melodi lagu/ notasi dengan harga notasi dari 1 ketukan menjadi $1 \frac{2}{2}$ ketukan.

Contoh yang sama dengan menggubah lirik lagunya adalah lagu yang berjudul "Kalau Kau Suka Hati Tepuk Tangan", (Bahasa Indonesia) dengan lagu aslinya yang berjudul "If You're Happy and You Know it Clap Your Hand" (bahasa Inggris). Jika dijabarkan liriknya adalah sebagai berikut :

Bahasa Inggris

Lyric :

If You're Happy and You Know it Clap Your Hand (Clap Hands Twice)

If You're Happy and You Know it Clap Your Hand (Clap Hands Twice)

If You're Happy and You Know it

Then Your Face will Surely Show it

If You're Happy and You Know it Clap Your Hand (Clap Hands Twice)

etc

Bahasa Inggris

Lirik

Kalau Kau Suka Hati Tepuk Tangan (prok2)

Kalau Kau Suka Hati Tepuk Tangan (prok2)

Kalau Kau Suka Hati Mari Kita Lakukan
Kalau Kau Suka Hati Tepuk Tangan (prok2)

Dari lirik berbahasa Inggris, kemudian dirubah dalam bahasa Indonesia. Maka dapat dilihat bahwa lagu dengan berbahasa Indonesia tidak mengalami perubahan dengan kata sahut menyahut yang sama yaitu "clap hands twice" dengan "prok....prok", maka tidak setiap kegiatan pembelajaran untuk tingkat penguasaan kosa kata yang ada di lirik lagu selalu diiringi/disertakan dengan pemanfaatan lagu anak (Sinaga, 2010). Hal tersebut bisa jadi disebabkan karena beberapa lagu anak tersebut tidak sesuai dengan tema pembelajaran yang ada dan pembelajaran lagu yang disampaikan guru belum tentu juga sesuai dengan kondisi lingkungan anak, misalnya kadangkala guru masih juga menyampaikan materi pembelajaran dengan menggunakan bahasa daerah. Secara umum, kondisi siswa yang berada di wilayah daerah belum dapat menerima pembelajaran musik dengan menggunakan bahasa Inggris. Hanya beberapa guru yang mengajar di daerah kota kebanyakan/ tidak sedikit yang menggunakan syair/ bait lagu mengunakan bahasa Inggris. Dari 11 tema pembelajaran, terdapat 5 tema yang khusus memanfaatkan lagu anak sebagai media. Terdapat beberapa tema yaitu kebutuhan, rekreasi, alam semesta, dan komunikasi yang memiliki keterbatasan guru dalam memilih lagu anak sebagai media.

Penciptaan Lagu

Penciptaan lagu pada hakekatnya adalah kecakapan dalam pengorganisasian elemen nada yang selaras dan serasi menjadi satu kesatuan dalam unsur ritme, dinamika, tempo, melodi, tangga nada, birama, harmoni, timbre yang seimbang dan proporsi sebagai pengaktualisasian ide melalui indra manusia. Dalam mencipta lagu anak usia dini (sederhana), guru harus memahami mengenal ilmu harmoni dan ilmu bentuk supaya lagu yang diciptakan memiliki susunan yang dapat diimplementasikan pada pelaksanaan pembelajaran anak usia dini. Untuk dapat mengoptimalkan proses penciptaan lagu anak, maka ditentukanlah Langkah-langkah berkarya tersebut. Dalam aktivitas perkuliahan pada mata kuliah Keterampilan Seni Musik dengan materi Cipta Lagu Anak Usia Dini semester V tahun akademik 2019-2020, ditunjukkan langkahlangkah mencipta lagu anak sebagai berikut: 
1. Menentukan tema.

2. Melanjutkan dengan menentukan spesifikasi binatang yang akan dijadikan subjek penciptaan lagu.

3. Menceritakan subtema menjadi beberapa paragraf (mendeskripsikan).

4. Menandai/ mengutip intisari dari deskripsi subtema tersebut untuk menjadi lirik lagu.

5. Membuat bagan lagu (verse, bridge, reff dll.). sebelumnya pengampu mata kuliah membagikan lembaran bagan melodi dalam bentuk notasi dengan berbagai motif, harga notasi, dan birama yang bervariatif. Dengan identifikasi kemapuan personal

a. Kelompok mahasiswa dengan kemampuan memainkan alat musik. Pencarian nada dilakukan dari trinada pada chord yang dimainkan, misalkan ditentukan biramanya misal 4/4, nada dasarnya $\mathrm{C}=$ Do, menentukan urutan chord-nya (C... F... G... C...), menjabarkan trinada (chord $\mathrm{C}=\mathrm{C}-\mathrm{E}-\mathrm{G}$, chord $\mathrm{F}=\mathrm{F}-\mathrm{A}-\mathrm{C}$, chord $\mathrm{G}=\mathrm{G}-\mathrm{B}-\mathrm{D})$, atau dengan menggunakan notasi angka (chord $\mathrm{C}=1-3-5$, chord $\mathrm{F}=4-6-1$, chord $\mathrm{G}=5-7$ 2). Dalam membuat bagan bait lagu (kalimat tanya), usahakan gunakan notasi trinada terendah misalnya dari 1 atau 3 . Dalam membuat bagan reff lagu (kalimat jawab), gunakan notasi trinada sedang dan/atau tinggi misalnya dari 5 atau 1 (tinggi).

b. Kelompok mahasiswa dengan kemampuan solfegio. Dari lembaran bagan melodi dalam bentuk notasi dengan berbagai motif, harga notasi, dan birama yang bervariatif. Mahasiswa melagukan penggalan motif melodi, dan kemudian melanjutkan hingga membentuk alunan lagu yang runtut. Setelah itu, memasukkan lirik.

c. Kelompok mahasiswa dengan tidak memiliki kemampuan musik. Pada materi perkuliahan sebelumnya, mahasiswa diberikan materi notasi musik dengan media interaktif sederhana berupa aplikasi/ software musik Encore 5.0. aplikasi/ software tersebut sengaja diberikan agar nantinya dapat menjawab kebutuhan mahasiswa dalam mencipta lagu, khususnya bagi mereka yang tidak dapat memainkan alat musik dan tidak memiliki kemampuan bidik nada/ solfegio. Melalui lembaran bagan melodi dalam bentuk notasi dengan berbagai motif, harga notasi, dan birama yang dipilih, notasi tersebut diketikkan dalam aplikasi tersebut dan kemudian mereka melanjutkan menulis/ mengetik notasi lanjutan sampai terbentuknya alunan melodi lagu. Setelah itu, memasukkan lirik.

Di bawah ini contoh karya cipta lagu mahasiswa yang sudah tervalidasi oleh dosen pengampu mata kuliah, dan nantinya juga dapat diaplikasikan untuk media pembelajaran di Pendidikan Anak Usia Dini.

Tema Binatang

1. Sub tema "Ayam Jago"

2. Deskripsi

Setiap pagi hari aku selalu mendengar suara ayam berkokok "kukuruyuk... kukuruyuk....", suara ayam tersebut membangunkan tidurku. Saat aku terbangun, aku bergegas menuju ke jendela, lalu ku buka jendela. $\mathrm{Ku}$ lihat dari kejauhan ada ayam berkokok di atas tembok rumahku. Kebetulan yang berkokok adalah ayam jantan dengan bulu-bulunya yang indah, bulu tersebut berwarna-warni. Terlihat juga jengger ayam yang kelihatan memerah. Ketika berkokok, ayam tersebut dengan gagahnya berdiri tegap sambil mengepak-ngepakkan sayapnya. Seandanya menjadi ayam peliharaanku, aku akan selalu merawat dengan memberi makam, memandikan supaya sehat selalu. Dan akan aku buatkan rumah/ kendang ayam supaya bisa berteduh dari hujan dan teriknya matahari.

3. Menentukan unsur musik

4. Birama $2 / 4$

5. Tempo 75 BPM

6. Nada Dasar (tentative)

7. Lirik:

Bait I

Kukuruyuk.. di pagi hari

Kukuruyuk. bangunkan tidurku

Kukuruyuk.. ku buka jendela

Ada ayam jantan berkokok di halaman

Bait II

Warna warni indah bulunya 
Jengger merah ketika berkokok

Seandainya aku memiliki

Akan aku rawat agar selalu sehat

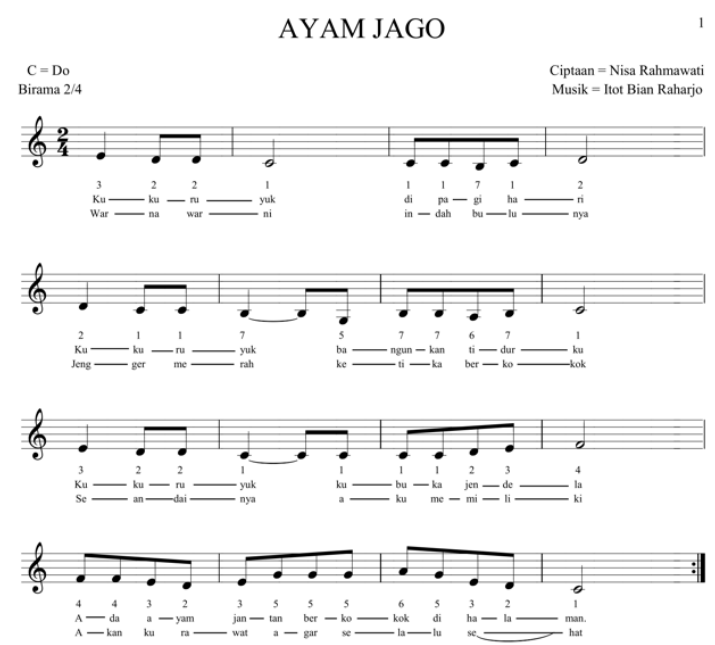

Gambar 1. Partitur Lagu "Ayam Jago"

Di atas merupakan lagu yang diciptakan oleh mahasiswa atas nama Nisa Rahmawati. Untuk penulisan partitur lagu, dosen mengarahkan karya cipta lagu supaya diportofoliokan dalam bentuk penulisan notasi angka dan balok yang dibuat dalam 1 sistem penulisan dari aplikasi/ software encore. Di bawah ini merupakan bukti autentik hasil cipta lagu mahasiswa yang menempuh perkuliahan Keterampilan Seni Musik Anak Usia Dini di semester V tahun akademik 2019-2020 yang didokumentasikan/ portofoliokan dalam galeri Instagram penulis.

Kendala dalam Mengembangkan Lagu Anak Usia Dini

Proses Penggubahan Lirik Lagu

Kesulitan dan kendala dalam pengembangan pemanfaatan lagu anak dalam kegiatan pembelajaran berbasis tema telah dialami oleh beberapa guru yang sedang menempuh pendidikan strata-1 di Prodi PG-PAUD FKIP Universitas Nusantara Kediri. Dari hasil wawancara secara langsung dan angket yang disebar, ada sebagian guru yang dapat mengganti lirik lagu sesuai dengan tema yang hendak diberikan. Seperti contoh mengubah lirik lagu "Bintang Kecil" menjadi lirik bermuatan Pendidikan karakter (aspek perkembangan Nilai Agama dan Moral) yang disampaikan berdasarkan momentum bulan Ramadan. Karena lagu "Bintang Kecil" sudah tidak asing untuk didengarkan anak, maka dengan mengganti lirik tersebut anak tidak akan merasa kesulitan untuk menghafalkan lagu tersebut. Biasanya penggubahan seperti ini dapat menarik perhatian anak, sehingga pelaksanaan pembelajaran dapat berlangsung dalam suasana yang menyenangkan. Hal tersebut dikarenakan anak mulai distimulus dengan pengalamanpengalaman baru.

Kendala berikutnya adalah saat memilih dari 11 tema pembelajaran, tidak semua tema yang dipelajari dalam aktivitas belajar yang terprogram secara harian maupun mingguan. Supaya lebih bervariatif dalam penyampaian tema pembelajaran lainnya, guru juga memilih untuk menyampikan dalam bentuk aktivitas bercerita (story telling) dan juga menyampaikan tema pembelajaran melalui aktivitas seni rupa lainnya. Keterbatasan yang dialami guru ketika mengajarkan tema melalui lagu anak adalah keterbatasan guru dalam hal perbendaharaan lagu, terlebih adalah kesulitan guru dalam membaca notasi (angka atau balok). Notasi angka dan balok dari lagu yang sudah ada, dan lagu baru yang sudah ada penulisan notasi musiknya. Biasanya lagu yang dikenal maupun lagu yang belum dikenal bisa didapat dari download google, browsing youtube, buku lagu anak, kaset dan CD/VCD yang dimiliki Lembaga. Proses Mencipta Lagu

Kendala mendasar yang dihadapi oleh guru (pencipta pemula) yang sedang menempuh Pendidikan strata-1 di PG-PAUD FKIP Universitas Nusantara PGRI Kediri sangat beragam. Kendala yang dihadapi oleh sebagian mahasiswa yang memiliki kemampuan memainkan alat musik gitar, sebagian mahasiswa yang memiliki kemampuan bidik nada (solfegio), dan yang tidak memiliki kemampuan keduanya adalah:

1. Kecenderungan kemiripan melodi lagu yang dibuat dengan lagu yang sudah ada;

2. Kadang alur melodi yang dibuat tidak nyambung antara verse menuju reff;

3. Kebiasaan mencipta lagu yang sepenggalsepenggal;

4. Kadang tercipta verse terlebih dahulu, kemudian reff-nya kadang sebaliknya;

5. Ketergantungan pada aplikasi dalam mencipta sehingga lebih mengutamakan 
media interaktif daripada kemauan berusaha untuk bisa memainkan alat musik dan kemauan untuk berusaha belajar solfegio.

6. Melodi yang dibuat melalui aplikasi kadang tidak harmonis dengan trinada (chord) serta kadang alur melodi lagunya cenderung tidak terarah (lompat-lompatan melodi yang tidak beraturan).

Demikian identifikasi kendala yang dihadapi mahasiswa yang bukan dari background musik seperti mahasiswa dari pendidikan musik maupun dari musik murni.

\section{Pembahasan}

Upaya dalam meningkatkan kompetensi dan kreativitas guru dalam memanfaatkan lagu sebagai media sesuai tema pembelajaran adalah melalui penggubahan atau mengganti lirik lagu yang sudah ada dengan lirik baru yang sesuai dengan tema. Kendala yang dihadapi ketika menggubah/ mengganti lirik pada umumnya adalah terkadang belum dapat memertimbangkan jumlah suku kata yang seharusnya disesuaikan dengan alur melodi lagu aslinya. Bisa saja mengurangi kalimat, bisa saja menambahkan kalimat, dan bisa jadi menambahkan notasi yang sama dengan harga notasi lebih cepat pada beberapa birama. Perubahan notasi tersebut bisa di awal kalimat lagu, bisa juga ada di akhir kalimat lagu yang ada di verse maupun reff.

Dalam mencipta lagu anak usia dini sesuai tema pembelajaran sangat membantu dalam menyampaikan materi yang hendak diberikan serta dapat bermanfaat menambah perbendaharaan lagu anak dalam pembelajaran, baik sebagai media peningkatan aspek perkembangan maupun sebagai apersepsi menuju tema pembelajaran yang sudah dirancang oleh guru. Kendala yang dihadapi oleh pencipta lagu pemula sangat beraneka ragam, mulai dari melodi lagu yang diciptakan atau dirangkai cenderung mirip dengan lagu yang sudah ada; alur melodi lagu terkadang tidak runtut dalam satu rangkaian (verse menuju ke reff); bisanya dalam mencipta lagu selalu diperoleh gambaran melodi lagu yang sepenggal-sepenggal dan kadang mucul saat spontanitas; kadang terciptanya bagan verse, kadang tercipta bagan reff-nya serta bahkan sebaliknya; ketergatungan pada aplikasi dalam mencipta sehingga lebih mengutamakan media interaktif ketimbang kemauan berusaha untuk bisa memainkan alat musik dan kemauan untuk berusaha belajar solfegio. Melodi yang dibuat melalui aplikasi kadang tidak harmonis dengan trinada (chord) serta kadang alur melodi lagunya cenderung tidak terarah (lompat-lompatan melodi yang tidak beraturan).

\section{KESIMPULAN}

Dari hasil penelitian dan pembahasan di atas maka dapat disimpulkan bahwa penggubahan lirik lagu dapat meningkatkan kreativitas guru dalam menambah perbendaharaan lagu anak usia dini sebagai media pembelajaran maupun aprersepsi menuju inti pembelajaran yang sesuai dengan tema yang sudah direncanakan. Kemudian, mencipta lagu baru adalah alternatif pilihan dalam menambah perbendaharaan lagu anak usia dini. Sementara, kendala yang dihadapi selama berproses menggubah maupun mencipta dapat diminimalisir dengan cara pembiasaan berproses/ latihan yang dilakukan secara berulang ulang.

\section{DAFTAR PUSTAKA}

Ammer, C. (1979). Harpers Dictionary of Music. Harpercollins Publisher.

Arostiyani, D. (2013). Pemanfaatan Lagu AnakAnak Sebagai Media Pendidikan Karakter Di Taman Kanak-Kanak Aisyiyah Desa Linggapura Kecamatan Tonjong, Brebes. Universitas Negeri Semarang.

Cutietta, R. A. (2013). Raising Musical Kids: A Guide for Parents (2nd ed.). Oxford University Press.

Debeturu, B., \& Wijayaningsih, E. L. (2019). Meningkatkan Kreativitas Anak Usia 5-6 Tahun melalui Media Magic Puffer Ball. Jurnal Obsesi Jurnal Pendidikan Anak Usia Dini, $3(1)$. https://doi.org/https://doi.org/10.31004/obs esi.v3i1.180

Depdiknas. (2008). Kamus besar bahasa Indonesia (4th ed.). Gramedia pustaka utama.

Peraturan Pemerintah Republik Indonesia, (2021). https://peraturan.bpk.go.id/Home/Downloa d/157902/PP Nomor 57 Tahun 2021.pdf

Undang-Undang Republik Indonesia, 37 (2003). https://peraturan.bpk.go.id/Home/Downloa d/32160/UU Nomor 20 Tahun 2003.pdf

Mahmud, A. T., \& Fat. (1994). Musik dan Anak. Proyek Pendidikan Tenaga Akademik Depdikbud.

Mashudi, T. (2013). Karakteristik Umum Pembelajaran di Sekolah Dasar. 
Itot Bian Raharjo ${ }^{1}$, Warih Handayaningrum ${ }^{2}$, Autar Abdillah ${ }^{3}$

Pengembangan dan Pemanfataan Tema Pembelajaran Dalam Penggubahan dan Penciptaan

Lagu Anak Usia Dini

https://masguruonline.wordpress.com/2013

/05/20/karakteristik-umum-pembelajaran-

di-sekolah-dasar/

Miles, B. M., Huberman, A. M., \& Saldana, J. (2014). Qualitative Data Analysis A Methods Sorcebook (3rd ed.). Sage Publications, Inc. UIP

Munfarijah, S. (2015). UPAYA MENINGKATKAN MOTIVASI KERJA DAN KREATIVITAS DALAM KEPEMIMPINAN PAUD. Jurnal Kependidikan, 3(2), 163-182. http://dx.doi.org/10.24090/jk.v3i2.905

Negara, G. B. (2019). Pemanfaatan Musik Sebagai Media Pembelajaran Dengan Metode Montessori Di Taman Kanak-Kanak Bambini Montessori Yogyakarta [Institut Seni Indonesia Yogyakarta]. http://digilib.isi.ac.id/5902/

Rachmawati, Y. (2005). Musik Sebagai Pembentuk Budi Pekerti : Sebuah Panduan Untuk Pendidikan. Panduan.

Randel, D. M. (1986). 'Arangement' The New Harvard Dictionary of Music (The Belknap Press of Harvard Univerity Press (ed.)).

Semiawan, C. R. (2002). Belajar dan pembelajaran dalam taraf pendidikan usia dini (pendidikan prasekolah dan sekolah dasar). Prenhallindo.

Sheppard, P. (2007). Music Makes Your Child Smarter: How Music Helps Every Child's Development. Schirmer Trade Books.

Sinaga, S. S. (2010). Pemanfaatan dan pengembangan lagu anak-anak dalam pembelajaran tematik pada pendidikan anak usia dini/tk. Harmonia: Journal of Arts Research and Education, 10. https://doi.org/https://doi.org/10.15294/har monia.v10i1.55

Suwono. (2011). Pengembangan Permainan Instrumentalia Musik Perkusi Berbasis Budaya Lokal Untuk Meningkatkan Kecerdasan Majemuk Anak Usia Dini [Universitas Islam Negeri Sunan Kalijaga Yogyakarta]. https://digilib.uinsuka.ac.id/id/eprint/6861/

Yustisia, T. P. (2007). Panduan Penyusun KTSP Lengkap; Kurikulum Tingkat Satuan Pendidikan SD, SMP, dan SMA. Pustaka Yustisia. 